\title{
Stopping Financial Fraud in Churches
}

\author{
Dahli Gray (Corresponding Author) \\ CGMA, CPA, CMA, CFE, DBA \\ Graduate School Division, Keiser University \\ 1900 W. Commercial Blvd., Fort Lauderdale, FL 33309, United States \\ Tel: 1-443-465-4559Ｅ-mail: DGray@ KeiserUniversity.edu \\ Rodrigo Villamarin \\ Business Owner, Villamarin Group Corporation \\ 6420 NW 114th Ave Suite 1335, Doral, FL 33178, United States \\ Tel: 1-305-979-3451Ｅ-mail: villamaringroup@gmail.com
}

Received: August 15, 2015 Accepted: September 18, 2015 Published: September 25, 2015

doi:10.5296/wjbm.v1i2.8162 URL: http://dx.doi.org/10.5296/wjbm.v1i1.8162

\begin{abstract}
This article reports the results of a survey administered in March 2015 about financial fraud in churches, which has been and continues to be a concern academics and professionals must address. The survey results focus on concepts and techniques for preventing, detecting, and resolving church financial fraud. Two hundred (200) adults were invited to complete the survey. Sixty five percent $(65 \%)$ responded providing strong support for changes such as requiring churches to apply for tax-exempt status, provide financial statements based on strong internal control systems, and use consultants (e.g., Certified Public Accountants, Certified Fraud Examiners) to help develop and implement changes.
\end{abstract}

Keywords: Church fraud, CPA, CFE, Financial fraud, Accounting, Sarbanes-Oxley act, Tax-exempt status, Internal control 


\section{MInstitute Macrothink $_{\text {Int }}$}

\section{Introduction}

The Center for the Study of Global Christianity projected in 2013 that fraud accounts for USD $\$ 37$ billion, or nearly 6\%, of the $\$ 594$ billion in total contributions given to churches (Pavlo, 2013). However, this is only an estimate, with actual figures believed to be higher because many acts of fraud within churches are never reported (Pavlo, 2013). The chronic magnitude of financial fraud in churches motivated this study. This article presents the results of a survey administered in March 2015 that posed questions related to the basic research question of how to stop church fraud. This included whether churches should have to apply for IRS 501(c)(3) status, be required to provide financial statements, require internal control procedures in financial record keeping, be required to follow the Sarbanes-Oxley Act, or if they should use consultants to help prevent, detect, and resolve financial fraud. The majority of the survey respondents answered yes to all of these questions and expressed support for the methods suggested to decrease church financial fraud. First, we describe the research methodology used and the respondents' demographic characteristics. We then discuss the survey results, which includes reviewing selected publications from financial fraud literature and then we close by providing concluding remarks with recommendations for future research.

\section{Methodology}

A survey was administered online in March 2015 using Survey Monkey to invite 200 individuals to participate. The invitation resulted in a response rate of $65 \%$ (i.e., 130 of the 200 eligible participants completed $98 \%$ or more of the survey). The survey posed 21 questions plus four demographic questions and included a final item that gave respondents an opportunity to provide additional comments, which in turn added insights into the issue of church financial fraud. Only eight individuals typed in additional feedback. The following is broadly representative of the eight comments: "Churches raise large amounts of money, and they should not be exempt from any laws that all businesses must adhere to." We next summarize survey respondents' demographics.

\section{Respondent Demographics}

The demographic information for the survey respondents is summarized in Tables 1-4. Of the respondents, $72 \%$ were female and $28 \%$ male (Table 1 ).

Table 1. Gender of survey respondents

\begin{tabular}{lc}
\hline Female & $72 \%$ \\
\hline Male & 28 \\
\hline
\end{tabular}

The respondents' ages were as follows: none were less than 18 years of age, $15 \%$ were between 18 and 29, 20\% were between 30 and 44, 45\% were between 45 and 59, and 20\% were 60 years old or older (Table 2). 


\section{Macrothink}

World Journal of Business and Management

Table 2. Ages of survey respondents

\begin{tabular}{lc}
\hline Less than 18 years old & Zero \\
\hline 18 to 29 years old & $15 \%$ \\
\hline 30 to 44 years old & 20 \\
\hline 45 to 59 years old & 45 \\
\hline 60 years old or older & 20 \\
\hline
\end{tabular}

In terms of household income, 5\% had household income between $\$ 0$ and $\$ 24,999,32 \%$ had household income between $\$ 25,000$ and $\$ 74,999,23 \%$ had household income between $\$ 75,000$ and $\$ 124,999,12 \%$ had household income between $\$ 125,000$ and $\$ 174,999,9 \%$ had household income of $\$ 175,000$ and over, and $19 \%$ preferred not to report household income (Table 3).

Table 3. Income of survey respondents

\begin{tabular}{lc}
\hline Zero to $\$ 24,999$ & $5 \%$ \\
\hline$\$ 25,000$ to $\$ 74,999$ & 32 \\
\hline$\$ 75,000$ to $\$ 124,999$ & 23 \\
\hline$\$ 125,000$ to $\$ 174,999$ & 12 \\
\hline$\$ 175,000$ and up & 9 \\
\hline Preferred not to say & 19 \\
\hline
\end{tabular}

The survey respondents lived in the following US regions: New England (8\%), Middle Atlantic (21\%), Central (34\%), Mountain (4\%), South Atlantic (18\%), and Pacific (15\%) (Table 4).

Table 4. United States region where survey respondents live

\begin{tabular}{lc}
\hline New England & $8 \%$ \\
\hline Middle Atlantic & 21 \\
\hline Central & 34 \\
\hline Mountain & 4 \\
\hline South Atlantic & 18 \\
\hline Pacific & 15 \\
\hline
\end{tabular}

The survey results are presented next with selected financial fraud literature included.

\section{Results}

The survey results address the following topics: 501(C)(3) status, financial statements, internal control procedures (Sarbanes-Oxley Act, vacations, bank checks, financial 
institutions, and surveillance), trusted individuals as fraudsters, excessive lifestyle as a potential indicator of fraud, and potential help from consultants (e.g., accounting firms) to prevent, detect, and resolve fraud.

\subsection{1(c)(3) Status}

Churches can assume Internal Revenue Service (IRS) 501(c)(3) status (see http://www.irs.gov/Charities-\&-Non-Profits/Charitable-Organizations/Exemption-Requireme nts-Section-501(c)(3)-Organizations) granting exemption from federal taxes without the requirement to apply for tax-exempt status. Seventy-four percent of the survey respondents felt that churches should have to apply for 501(c)(3) status (Table 5).

Table 5. Church application for 501(c)(3) status

\begin{tabular}{lc}
\hline \multicolumn{1}{c}{ Answer Choices } & $\begin{array}{c}\text { Response (\%) } \\
\mathrm{n}=130\end{array}$ \\
\hline Churches should be required to apply for 501(c)(3) status. & 74 \\
Churches should not be required to apply for 501(c)(3) status. & 16 \\
No opinion & 10 \\
Total & 100 \\
\hline
\end{tabular}

Most vendors require documentation when a church wishes to make a purchase and not pay sales tax, such as a copy of the IRS 501(c)(3) certification stating that the church has 501(c)(3) status. This motivates churches to apply for 501(c)(3) status from the IRS. As of 2015, a church has only to do this once. Sixty percent of the survey respondents felt that churches should apply every year (39\%) or every other year (21\%) (Table 6).

Table 6. Church sales tax exemption and 501(c)(3) application

\begin{tabular}{lc}
\hline \multicolumn{1}{c}{ Answer Choices } & $\begin{array}{c}\text { Response (\%) } \\
\mathrm{n}=130\end{array}$ \\
\hline Churches should only have to apply once for 501(c)(3) status. & 29 \\
Churches should have to apply each year for 501(c)(3) status. & 39 \\
Churches should have to apply every other year for 501(c)(3) status. & 21 \\
No opinion & 11 \\
Total & 100 \\
\hline
\end{tabular}

When it comes to churches and religion, the United States government has maintained some distance to comply with the separation of church and state clause in the First Amendment of the US Constitution, "Congress shall make no law respecting an establishment of religion, or prohibiting the free exercise thereof" (Cornell, 2015, para. 2). Therefore, the tax laws that govern churches and religious organizations are purposely broad and sometimes vague. For 
instance, the terms religion, religious, and church are not precisely defined by the Internal Revenue Code or the US Treasury Department. Nonetheless, for tax purposes, churches are considered charities, which are governed by Section 501(c)(3) of the tax code (IRS, 2012), wherein organizations meeting the criteria to be considered a church are automatically tax exempt. This is generally defined as a place of worship that promotes the advancement of religion. In addition, a church that meets the basic requirements of Section 501(c)(3) is exempt from filing an annual report on its finances on forms 990, 990-EZ, or 990-N. Although these exemptions are extremely beneficial for churches, they facilitate an atmosphere of minimal accountability where fraudulent activity can easily take place. Given that churches are not required to file annual reports, many might not feel a need to properly maintain financial records. Without effective internal controls, financial resources may not be managed professionally, making them vulnerable to financial fraud.

In the 1970s, partly as a result of these reporting problems, public concerns about questionable fundraising practices in the nonprofit sector put the self-governing privileges of churches at risk. Consequently, "Senator Mark Hatfield addressed a group of key Christian leaders and challenged them to police their own mission agencies as a 'Christian Better Business Bureau' or face the potential of government intervention” (ECFA, 2015, para. 3). Subsequently, in an effort to solve this problem, the Evangelical Council for Financial Accountability (ECFA) was founded in 1979 with the primary objective of accrediting Christian nonprofit organizations that adhere to its accountability, fundraising, and governance standards. Although the ECFA has contributed significantly to the fight against financial fraud in churches, the organization is only affiliated with Christian nonprofit organizations. Therefore, there is still much work ahead in preventing and reducing fraud among 501(c)(3) organizations.

\subsection{Church Financial Statements}

Churches are not legally required to provide annual financial statements to the IRS, state tax authorities, or church members. Thirty-one percent of the survey respondents felt that churches should provide annual financial statements to church members (Table 7). Forty-two percent felt that churches should provide annual financial statements to both church members and government agencies, such as the IRS (Table 7).

Table 7. Requirement to provide financial statements

\begin{tabular}{lc}
\hline \multicolumn{1}{c}{ Answer Choices } & $\begin{array}{c}\text { Response (\%) } \\
\mathrm{n}=128\end{array}$ \\
\hline $\begin{array}{l}\text { Churches should provide annual financial statements to church members. } \\
\text { Churches should provide annual financial statements to church members } \\
\text { and government agencies (e.g., IRS). }\end{array}$ & 31 \\
$\begin{array}{l}\text { Churches should provide annual financial statements to the IRS as part of } \\
\text { an annual application for 501(c)(3) status }\end{array}$ & 42 \\
No opinion & 19 \\
Total & 8 \\
\hline
\end{tabular}




\subsection{Internal Control Procedures}

Churches are not legally required to have internal control procedures to protect church assets. Sixty-five percent of the survey respondents felt that these should be required (Table 8).

Table 8. Churches and internal control procedures

\begin{tabular}{lc}
\hline \multicolumn{1}{c}{ Answer Choices } & $\begin{array}{c}\text { Response (\%) } \\
\mathrm{n}=128\end{array}$ \\
\hline $\begin{array}{l}\text { Churches should be required to have internal control procedures in } \\
\text { order to protect church assets. }\end{array}$ & 65 \\
$\begin{array}{l}\text { Churches should not be required to have internal control procedures in } \\
\text { order to protect church assets. }\end{array}$ & 27 \\
No opinion & 8 \\
Total & 100 \\
\hline
\end{tabular}

The case of Angela Fine, a former church secretary who accrued more than $\$ 14,000$ in false expenses from February 2006 through August 2007 (Wolford, 2008) provides an illustrative example. Angela Fine employed a very common means of embezzlement to defraud the institution: payroll and the organization's credit card. She requested an unauthorized raise of $\$ 1$ per hour by calling the church accountant and misrepresenting herself as the pastor, Lane-Lawrence. In addition, Fine used the church's credit card to purchase personal items amounting to $\$ 6,033$ (Wolford, 2008). It is evident that poor internal controls enabled this situation. If the church had an established set of procedures for salary increases, such as having a church authority or secretary review and approve the raise, this fraud could have been prevented. Similarly, if the credit card statements were reviewed on a monthly basis, the personal items Fine purchased would have been identified sooner. A second case involves a Ponzi scheme perpetrated by Ephren Taylor, who was arrested on federal fraud charges in June 2014. In 2009, Taylor initiated his "Building Wealth Tour," which was strategically designed to defraud church members by manipulating their trust while promoting his services as a financial advisor. According to the Department of Justice (DOJ), Taylor "pushed people to invest in ' 100 percent risk free' sweepstakes machines, or computers with games where players can win cash prizes" (ABC News, 2014, para. 9). Regrettably, many church members participated and lost their life savings and retirement funds. The Securities and Exchange Commission (SEC) ordered him to pay back $\$ 14$ million to investors, which included interest and fees (ABC News, 2014). Internal controls include the Sarbanes-Oxley Act, vacation management, financial institutions, check management, and surveillance as presented next.

\subsection{Sarbanes-Oxley Act}

The Sarbanes-Oxley Act of 2002 (SOX) was passed in response to the major Enron accounting fraud and enacted increased fraud protections, such as internal controls. Gray and Ehoff (2015) found via analyzing actual fraud cases that the SOX and the Dodd Frank Acts 


\section{Macrothink}

World Journal of Business and Management

ISSN 2377-4622

2015, Vol. 1, No. 2

did not eliminate financial fraud subsequent to being to being legislated. Part of the reason is that not all organizations are required to meet the SOX or Dodd Frank requirements. Churches are not required to meet the SOX requirements. Thirty-nine percent of the survey respondents felt that all organizations, including churches, should be required to follow SOX (Table 9). Twenty-one percent felt that SOX should only apply to large public companies, as it is too expensive for other organizations (including churches) to implement (Table 9). Twenty-nine percent felt that SOX should apply to all large organizations, including large churches (Table 9).

Table 9. Sarbanes-Oxley Act of 2002

\begin{tabular}{lc}
\hline \multicolumn{1}{c}{ Answer Choices } & $\begin{array}{c}\text { Response (\%) } \\
\mathrm{n}=123\end{array}$ \\
\hline $\begin{array}{l}\text { The SOX is a law that all organizations, including churches, should be } \\
\text { required to follow. }\end{array}$ & 39 \\
$\begin{array}{l}\text { The SOX is a law that should only apply to large public companies, as it } \\
\text { is too expensive for other organizations (including churches) to comply } \\
\text { with. The cost exceeds the benefits. }\end{array}$ & 21 \\
The SOX is a law that should apply to large organizations, including large \\
churches. Small organizations cannot afford to implement the internal \\
control requirements. \\
$\begin{array}{l}\text { No opinion } \\
\text { Total }\end{array}$ \\
\hline
\end{tabular}

\subsection{Vacation Management}

Forty percent of the survey respondents felt that if the Church bookkeeper and/or accountant does not want to take a vacation, then someone else should assume their duties on a random basis to minimize opportunities for fraud (Table 10). Twenty-four percent felt that it is appropriate to lock records and for transactions to wait until the bookkeeper and/or accountant returns from taking one or two vacations days (Table 10). Twenty percent felt that someone else should assume these duties, whether the vacation is only a single day or many consecutive days (Table 10).

Table 10. Bookkeeper and/or accountant vacation with someone else assuming duties

\begin{tabular}{lc}
\hline \multicolumn{1}{c}{ Answer Choices } & $\begin{array}{c}\text { Response (\%) } \\
\mathrm{n}=128\end{array}$ \\
\hline $\begin{array}{l}\text { If the bookkeeper and/or accountant takes vacation days one or two } \\
\text { days at a time, then it is okay for the records to be locked and } \\
\text { transactions to wait until the bookkeeper and/or accountant returns. }\end{array}$ & 24 \\
\hline
\end{tabular}


Someone else should assume the bookkeeper's and/or accountant's

duties, regardless of whether the vacation is one day or many days in a

row.

If the bookkeeper and/or accountant do not want to take a vacation, then someone else should assume their duties on a random basis to help minimize the opportunity for fraud.

No opinion

Total

\subsection{Financial Institutions}

Ninety-six percent of the respondents felt that comparing the financial institution's online images of a cashed check to the information in the church financial records was important (Table 11).

Table 11. The financial institution's image of the cashed check should be compared to the information in the church financial records

\begin{tabular}{lc}
\hline \multicolumn{1}{c}{ Answer Choices } & Response (\%) \\
& $\mathrm{n}=112$ \\
\hline Very to extremely important & 73 \\
Slightly to moderately important & 23 \\
Not important & 4 \\
Total & 100 \\
\hline
\end{tabular}

Ninety-two percent felt that it was important for financial institutions to send a text message or email upon receipt of a check before it clears, with an option to stop it (Table 12).

Table 12. The financial institution should send a text message or email upon receipt of a check but before it clears, with the option to stop it

\begin{tabular}{lc}
\hline \multicolumn{1}{c}{ Answer Choices } & Response (\%) \\
& $\mathrm{n}=112$ \\
\hline Very to extremely important & 51 \\
Slightly to moderately important & 41 \\
Not important & 8 \\
Total & 100 \\
\hline
\end{tabular}

Ninety-six percent felt that limiting the funds in the checking account to the budgeted monthly expenditures and that it is important to separate the checking accounts for operating 


\section{Macrothink}

World Journal of Business and Management

versus other expenditures (Table 13).

Table 13. The amount in the checking account should be limited to budgeted monthly expenditures, and separate checking accounts maintained for operating versus other expenditures

\begin{tabular}{lc}
\hline \multicolumn{1}{c}{ Answer Choices } & Response (\%) \\
& $\mathrm{n}=112$ \\
\hline Very to extremely important & 68 \\
Slightly to moderately important & 28 \\
Not important & 4 \\
Total & 100 \\
\hline
\end{tabular}

\subsection{Check Management}

Ninety-seven percent of respondents felt that it was important to require two people to sign checks (Table 14). Ninety-six percent felt that it was important to prohibit making a check out to cash (Table 15), and $97 \%$ felt that it was important not to allow checks to be signed in advance (Table 16).

Table 14. Checks should be signed by two people

\begin{tabular}{lc}
\hline \multicolumn{1}{c}{ Answer Choices } & Response (\%) \\
& $\mathrm{n}=112$ \\
\hline Very to extremely important & 68 \\
Slightly to moderately important & 29 \\
Not important & 3 \\
Total & 100 \\
\hline
\end{tabular}

Table 15. Checks are not to be made out to cash

\begin{tabular}{lc}
\hline \multicolumn{1}{c}{ Answer Choices } & $\begin{array}{c}\text { Response (\%) } \\
\mathrm{n}=111\end{array}$ \\
\hline Very to extremely important & 80 \\
Slightly to moderately important & 16 \\
Not important & 4 \\
No opinion & \\
Total & 100 \\
\hline
\end{tabular}


Table 16. Checks should not be signed in advance

\begin{tabular}{lc}
\hline \multicolumn{1}{c}{ Answer Choices } & Response (\%) \\
& $\mathrm{n}=111$ \\
\hline Very to extremely important & 81 \\
Slightly to moderately important & 16 \\
Not important & 3 \\
Total & 100 \\
\hline
\end{tabular}

\subsection{Surveillance}

Technology (e.g., cameras) has advanced over the years. Gray and Ladig (2015) reviewed fraud literature relative to technological advances to find that implementation of the technological advances tend to be postponed due to concerns about costs exceeding benefits. It appears that the survey respondents for this study feel that the benefits exceed the costs. Ninety-six percent of respondents felt that individuals should be informed about surveillance (e.g., cameras) used to help protect assets in advance (Table 17). Ninety-two percent felt that surveillance (e.g., cameras) can be part real and part "window dressing" (i.e., not real) and still help protect assets as long as individuals are unaware of which are real (Table 18).

Table 17. Individuals should be informed that surveillance (e.g., cameras) is being used to help protect assets

\begin{tabular}{lc}
\hline \multicolumn{1}{c}{ Answer Choices } & Response (\%) \\
& $\mathrm{n}=110$ \\
\hline Very to extremely important & 72 \\
Slightly to moderately important & 14 \\
Not important & 4 \\
Total & 100 \\
\hline
\end{tabular}

Table 18. Surveillance (e.g., cameras) can be part real and part "window dressing" (i.e., not real) and still help to protect assets as long as individuals do not know which forms of surveillance are real

\begin{tabular}{lc}
\hline \multicolumn{1}{c}{ Answer Choices } & $\begin{array}{c}\text { Response (\%) } \\
\mathrm{n}=108\end{array}$ \\
\hline Very to extremely important & 48 \\
Slightly to moderately important & 44 \\
Not important & 8 \\
Total & 100 \\
\hline
\end{tabular}




\subsection{Trusted Individuals as Potential Fraudsters}

Eighty-one percent of the respondents felt that trusted individuals (including ministers) should have their transactions and decisions verified (e.g., audited, documentation required) (Table 19) while 9\% felt that this should not be required (Table 19). There are examples where such a measure could have prevented fraud. For instance, in the case of Reverend Michael Jude Fay, a Roman Catholic priest sentenced to 37 months in prison after admitting to "pilfering \$1.3 million from the church he had led" (Cowan, 2007). In another example, Archie Larue Evans, the pastor of a North Carolina church and owner of a secular business called Gold \& Silver, LLC who used his influence and position of honor, respect, and trust, to defraud members of his congregation who lost thousands of dollars. Evans defrauded these individuals by presenting them with an investment opportunity through his secular business, promising a higher return than that offered by financial institutions (IRS, 2015). As this promise was impossible to fulfill, he developed a Ponzi scheme in which he used new investors' funds to pay the supposedly earned interest to his early investors. From January 2009 to October 2011, he "hid the fact that he had lost or spent the money invested with him by paying investors what he claimed to be their earned interest payments using funds he received from new investors" (IRS, 2015, p. 41). Investors' losses amounted to more than $\$ 2.5$ million, for which he was sentenced in 2014 to 84 months in prison and three years of supervised release, and ordered to pay $\$ 3,763,339$ in restitution for "mail fraud, conspiracy to structure transactions with a financial institution and money laundering” (IRS, 2015, p. 41).

Table 19. Trusted individuals as financial fraudsters

\begin{tabular}{lc}
\hline \multicolumn{1}{c}{ Answer Choices } & $\begin{array}{c}\text { Response (\%) } \\
\mathrm{n}=128\end{array}$ \\
\hline $\begin{array}{l}\text { Trusted individuals should have their transactions and decisions } \\
\text { verified (e.g., audited, documentation required). }\end{array}$ & 81 \\
$\begin{array}{l}\text { Trusted individuals except for the minister and/or preacher should } \\
\text { have their transactions and decisions verified (e.g., audited, } \\
\text { documentation required) }\end{array}$ & 9 \\
Trust with verification means there is no trust. If there is trust, then \\
verification should be neither required nor imposed. \\
$\begin{array}{l}\text { No opinion } \\
\text { Total }\end{array}$ \\
\hline
\end{tabular}

Pastor Barry Minkow defrauded both his San Diego church and his congregation. From 2001 to 2011, Minkow embezzled funds by taking donation checks, forging signatures on checks, and taking out unauthorized loans in the church's name (Associated Press, 2014). Altogether, Minkow stole a total of $\$ 3.5$ million in church funds. Minkow had a criminal history of fraud before becoming a pastor, serving an earlier sentence for "an unrelated scam that cost homebuilder Lennar Corp. some \$580 million in lost stock value" (Associated Press, 2014, para. 2). Minkow was prosecuted and sentenced to five years in federal prison. 


\subsection{Lifestyle Exceeding Income as a potential indicator}

When an individual's assets and/or lifestyle far exceed his or her official income, this may be a red flag indicating that fraud has occurred or is occurring. The survey participants were asked to read the following excerpt from a New York Times article entitled "Of Virtue and Vice, and a Vatican Priest" about Monsignor Nunzio Scarano, who was accused of money laundering (Casati, 2014):

"Before his arrest in June 2013, the monsignor was a top accountant at the Vatican office that, at that time, managed the Holy See's real estate and investments. He is currently on trial, accused of money laundering - most notably, of trying to smuggle \$26 million from Switzerland to Italy in a private plane, with the help of an Italian secret service agent. An Italian judge calculated Monsignor Scarano's wealth at more than $\$ 8.2$ million, though the Vatican paid the priest just $\$ 41,000$ a year. Italian authorities seized the 17 room, $\$ 1.7$ million house in Salerno, where he is now under house arrest, along with many bank accounts; two of them, at the Vatican Bank, were seized by Vatican authorities. ... Pope Francis has made significant changes in the Vatican financial system. He created a secretariat for the economy and hired consulting firms to conduct reviews of the entire financial system. The Vatican Bank's fortifications against money laundering have been strengthened by closing many accounts and clarifying qualifications for account holders".

Considering the above news report, $47 \%$ of the survey respondents concluded that when an individual's assets and/or lifestyle far exceed his or her official income, an investigation should be initiated without informing the individual, as doing so would provide an opportunity to create or destroy evidence (Table 20). Thirty-seven percent of respondents felt that the individual should be told about an investigation asked about the difference between their lifestyle and earned income, as the individual may have inherited significant assets (Table 20).

Table 20. Individual's assets and/or lifestyle

\begin{tabular}{lc}
\hline \multicolumn{1}{c}{ Answer Choices } & $\begin{array}{c}\text { Response (\%) } \\
\mathrm{n}=126\end{array}$ \\
\hline $\begin{array}{l}\text { When an individual's assets and/or lifestyle far exceed his or her official } \\
\text { income, an investigation should be initiated without informing the individual, } \\
\text { as doing so would give him or her an opportunity to create or destroy evidence. }\end{array}$ & 47 \\
When an individual's assets and/or lifestyle far exceed his or her official \\
income, the individual should be told that an investigation is being initiated \\
and asked why there is such a big difference. Maybe the individual inherited \\
the resources for the assets and lifestyle. \\
When an individual's assets and/or lifestyle far exceed his or her official \\
income, the cost to complete an investigation should not be incurred. Instead, \\
ask the individual why there is such a big difference. \\
No opinion \\
Total
\end{tabular}




\subsection{Potential Help from Consultants}

Based on the New York Times report indicating that Pope Francis "made significant changes in the Vatican financial system ... [including hiring] consulting firms to conduct reviews of the entire financial system" (Casati, 2014), 53\% of the survey respondents felt that churches should hire a consultant or consultants to conduct annual reviews of the church financial systems (Table 21 ), with $28 \%$ responding that this should occur once every three years (Table 21).

Table 21. Hiring consultants to review church financial systems

\begin{tabular}{lc}
\hline \multicolumn{1}{c}{ Answer Choices } & $\begin{array}{c}\text { Response (\%) } \\
n=126\end{array}$ \\
\hline $\begin{array}{l}\text { Churches should hire a consultant or consultants to conduct an annual } \\
\text { review of the church financial systems. }\end{array}$ & 53 \\
$\begin{array}{l}\text { Churches should hire a consultant or consultants to conduct a review } \\
\text { of the church financial systems once every three years. }\end{array}$ & 28 \\
$\begin{array}{l}\text { Churches should hire a consultant or consultants to conduct a review } \\
\text { of church financial systems once every five years. }\end{array}$ & 6 \\
$\begin{array}{l}\text { No opinion } \\
\text { Total }\end{array}$ & 13 \\
\hline
\end{tabular}

\subsection{Accounting Firm Consultants}

The survey respondents were asked to read the following excerpt from an AG Financial Solutions blog post entitled "Church Fraud: What Every Pastor Should Know" (AG Financial Solution, 2013).

"If you suspect fraud within your church, do not share this information with anyone involved in the process. Remember, the fraudster can be the most trusted member of your staff. Instead, talk to a local accounting firm that has an audit department and they will tell you what your next steps should be. If fraud has occurred, the best response is to involve the police. Although churches are often reluctant to do this, studies show that once a person has committed a fraud, they rarely stop on their own. If they simply get fired, they will likely go on to other organizations and commit the same crime. If the individual is prosecuted and convicted, the facts of the case become public knowledge, offering several benefits":

- Experiencing consequences may help the person stop committing fraud.

- Reporting the crime gives the church an opportunity to recover some of what was stolen. In fact, insurance companies usually require prosecution to take place for a church to be able to collect coverage on stolen goods.

- The church will be allowed to warn other employers of the fraudster. If they are not prosecuted, you will not be able to inform their next employer of the reason they 
were fired, and the cycle could continue.

Sixty-seven percent of the respondents felt that the article's advice was appropriate and should be followed (Table 22). Seven percent felt that if the fraud case became public knowledge, it could reflect badly on the church, and protecting the church's image is more important than the benefits listed above (Table 22). Twelve percent felt that not sharing the suspected fraud with anyone who might be involved in the fraud precludes the simpler approach of determining if there were errors that can be corrected once the concern is shared (Table 22).

Table 22. Disclosing church fraud

\begin{tabular}{lc}
\multicolumn{1}{c}{ Answer Choices } & $\begin{array}{c}\text { Response (\%) } \mathrm{n}= \\
119\end{array}$ \\
\hline $\begin{array}{l}\text { If the fraud case becomes public knowledge, it may reflect badly on } \\
\text { the church. Protecting the church image is more important than the }\end{array}$ & 7 \\
three benefits listed above. & 12 \\
The idea of not sharing the suspected fraud with anyone who may be & \\
involved in the fraud precludes a simpler approach, which is to \\
determine if there are errors that could be corrected once the concern \\
is shared. \\
The article's advice is appropriate and should be implemented. \\
No opinion \\
Total
\end{tabular}

Read the following excerpt from an AG Financial Solutions blog post entitled "Church Fraud: What Every Pastor Should Know." (AG Financial Solutions, 2013, September 19). Then select the response that best reflects your feelings about the material from the excerpt:

"If you suspect fraud within your church, do not share this information with anyone involved in the process. Remember, the fraudster can be the most trusted member of your staff. Instead, talk to a local accounting firm that has an audit department and they will tell you what your next steps should be. If fraud has occurred, the best response is to involve the police. Although churches are often reluctant to do this, studies show that once a person has committed a fraud, they rarely stop on their own. If they simply get fired, they will likely go on to other organizations and commit the same crime. If the individual is prosecuted and convicted, the facts of the case become public knowledge, offering several benefits: Experiencing consequences may help the person stop committing fraud. Reporting the crime gives the church an opportunity to recover some of what was stolen. In fact, insurance companies usually require prosecution to take place for a church to be able to collect coverage on stolen goods. The church will be allowed to warn other employers of the fraudster. If they are not prosecuted, you will not be able to inform their next employer of the reason they were fired, and the cycle could continue." 


\subsection{Management Accountants}

Typically, organizations (including churches) use management accountants as employees or consultants to collect and provide information that helps leaders and managers make decisions. Sixty-six percent of the respondents answered that it is very to extremely important to involve management accountants in budgeting or expenditure processes (Table 23). Sixty-two percent of respondents replied that it is very to extremely important to involve management accountants in the process of developing an approved list of vendors to help ensure that only valid suppliers are used and paid (Table 24). Fifty-six percent of respondents felt that it is very to extremely important to involve management accountants in the process of developing an expense-reporting system for direct billing, using a travel agency for travel costs, and obtaining pre-approval for expected expenses (Table 25).

Table 23. Management accountants should be involved in the processes of developing budgets as well as comparing budgeted to actual amounts; analysis should be conducted to help determine whether the budgeting process or expenditure process needs revision

\begin{tabular}{lc}
\hline \multicolumn{1}{c}{ Answer Choices } & Response $(\%) \mathrm{n}=114$ \\
\hline Very to extremely important & 66 \\
Slightly to moderately important & 15 \\
Not important & 7 \\
No opinion & 12 \\
Total & 100 \\
\hline
\end{tabular}

Table 24. Management accountants should be involved in the processes of developing an approved list of vendors and/or suppliers to help ensure that only valid vendors and/or suppliers are used and paid

\begin{tabular}{lc}
\hline Answer Choices & Response $(\%) \mathrm{n}=112$ \\
\hline Very to extremely important & 62 \\
Slightly to moderately important & 20 \\
Not important & 6 \\
No opinion & 12 \\
Total & 100 \\
\hline
\end{tabular}

Table 25. Management accountants should be involved in the process of developing an expense-reporting system for direct billing, using a travel agency for travel costs, and obtaining pre-approval for expected expenses

\begin{tabular}{lc}
\hline Answer Choices & Response $(\%) \mathrm{n}=112$ \\
\hline Very to extremely important & 56 \\
Slightly to moderately important & 26 \\
Not important & 6 \\
No opinion & 12 \\
Total & 100 \\
\hline
\end{tabular}




\section{Conclusions}

The two main contributors to fraud within churches are the lack of church accounting standards and regulations (e.g., laws) and the trusting mentality that pervades churches. Perhaps churches should be subject to New York's "strategy to get ahead of potential crises by 'stress testing' nonprofits that show signs of potential trouble" (Stewart, 2015) to address the problem. Given that the IRS oversight of nonprofit organizations has been undercut by a lack of funding, it is unlikely that IRS oversight of churches will increase. In an attempt to compensate, the IRS "unveiled a strikingly stripped-down online application last year [2014] to speed the process of applying for tax-exempt status" for nonprofit organizations (Cohen, 2015). Instead of increasing rigor to deter fraud, the application process may actually enable fraud "by not asking any questions about governance, conflicts of interest or function, and saying applicants don't have to reveal any such issues" (Cohen, 2015). The US government appears to be making it easier to commit fraud through reduced regulation, although the situation may require the opposite.

This article reported the results of a survey about possible ways to prevent, detect, and resolve the financial fraud plaguing churches in the US. The results indicate strong support for increased regulation of churches to decrease fraud. Perhaps the next question to examine is when part or all of a church becomes a business. While the separation of church and state is written into the US Constitution, clear definition of what the difference between a church and a business has yet to be developed. Additional research could help with the development of this definition. Even the Financial Accounting Standards Board (FASB) has been exploring a revised definition of what constitutes being a business (Gray \& Jorge, 2015). Revising the definition of what constitutes being a business impacts the definition of what constitutes the definition of all other types of organizations including churches. Additional research regarding this could be beneficial along with expanding the research to include religious organizations along with churches.

\section{References}

ABC News. (2014). Alleged church Ponzi schemer arrested on federal fraud charges. Retrieved on June 17, 2014 from http://abcnews.go.com/US/alleged-churchponzi-schemer-arrested-federal-fraud-charges/story?id=24182271

AG Financial Solutions. (2013). Church fraud: What every pastor should know. Retrieved on September 19, 2013 from http://blog.agfinancial.org/bid/98595/ChurchFraud WhatEveryPastorShouldKnow

Associated Press. (2014). Con man gets prison for San Diego church fraud. Retrieved on April 28, 2014 from http://www.nytimes.com/aponline/2014/04/28/us/ ap-us-repeat-con-man.html?_r=0

Casati, D. (2014). Of virtue and vice, and a Vatican priest: Some see Msgr. Nunzio Scarano, who is accused of money laundering, as a symbol of a financial system gone awry. Retrieved on October 18, 2014 from http://www.nytimes.com/2014/10/19/business/ of-virtue-and-vice-and-a-vatican-priest.html 


\section{I Macrothink}

World Journal of Business and Management

ISSN 2377-4622

2015, Vol. 1, No. 2

Cohen, P. (2015). I.R.S. shortcut to tax-exempt status is under fire. Retrieved on April 8, 2015 from http://www.nytimes.com/2015/04/09/business/irs-shortcut-to-tax-exempt-status-isunder-fire.html

Cornell University Law School (Cornell). (2015). First Amendment. Retrieved from https://www.law.cornell.edu/constitution/first_amendment

Cowan, A. L. (2007). 37-month sentence for priest who defrauded parish. Retrieved on December 5, 2007 from http://www.nytimes.com/2007/12/05/nyregion/05priest.html?_r=1\&

Evangelical Council for Financial Accountability (ECFA). (2015). ECFA history. Retrieved from http://www.ecfa.org/Content/GeneralBackground

Gray, D., \& Ehoff, C. (2015, $1^{\text {st }}$ Quarter). Sarbanes Oxley and Dodd Frank: Then There was Fraud. Journal of Business \& Economics Research, 13(1). 19-26. Retrieved from http://www.cluteinstitute.com/ojs/index.php/JBER/article/view/9076

Gray, D., \& Jorge, M. (2015, August). Accounting for goodwill at private and all other companies: Amortize, impair, or write-off. Business, Management and Economics Research, 1(4), 44-49.

Gray, D., \& Ladig, J. (2015, March). The Implementation of EMV Chip Card Technology to Improve Cyber Security Accelerates in the U.S. Following Target Corporation's Data Breach. International Journal of Business Administration, 6(2), 60-67. http://dx.doi.org/10.5430/ijba.v6n2p60

Internal Revenue Service (IRS). (2012). Churches and religious organizations [Video file]. $\begin{array}{lllll}\text { Retrieved on } & \text { July } & 25, & 2012 & \text { from }\end{array}$ http://www.irsvideos.gov/ChurchesReligiousOrganizations/player/frame-flv.htm

Internal Revenue Service (IRS). (2015). Examples of general fraud investigations-fiscal year 2014. Retrieved on April 1, 2015 from http://www.irs.gov/uac/Examples-of-General-FraudInvestigations-Fiscal-Year-2014

Pavlo, W. (2013). Fraud thriving in U.S. churches, but you wouldn't know it. Retrieved on November 18, 2013 from http://www.forbes.com/sites/walterpavlo/2013/11/18/ fraud-thriving-in-u-s-churches-but-you-wouldnt-know-it/

Stewart, J. B. (2015). Cooper Union inquiry puts nonprofits on notice. Retrieved on April 9, 2015 from http://www.nytimes.com/2015/04/10/business/cooper-union-inquiry-putsnonprofits-on-notice.html

Wolford, S. (2008). Ex-church secretary charged with fraud. Retrieved on April 2, 2008 from http://triblive.com/x/valleyindependent/news/s_560265.html\#axzz3Y42LIs3Q

\section{Copyright Disclaimer}

Copyright for this article is retained by the author(s), with first publication rights granted to the journal. 
This is an open-access article distributed under the terms and conditions of the Creative Commons Attribution license (http://creativecommons.org/licenses/by/3.0/). 